\title{
CORRECTION
}

\section{Correction: Acidity promotes tumour progression by altering macrophage phenotype in prostate cancer}

Asmaa El-Kenawi, Chandler Gatenbee, Mark Robertson-Tessi, Rafael Bravo, Jasreman Dhillon, Yoganand Balagurunathan, Anders Berglund, Naveen Vishvakarma, Arig Ibrahim-Hashim, Jung Choi, Kimberly Luddy, Robert Gatenby, Shari Pilon-Thomas, Alexander Anderson, Brian Ruffell and Robert Gillies

British Journal of Cancer (2020) 122:1118; https://doi.org/10.1038/s41416-019-0710-4

Correction to: British Journal of Cancer 121, 556-566; https:// doi.org/10.1038/s41416-019-0542-2, published online 16 August 2019

The author Naveen Vishvakarma was incorrectly listed as Naveen Visvakarma. The correct name is listed above.

\begin{abstract}
(i)
Open Access This article is licensed under a Creative Commons International License, which permits use, sharing, adaptation, distribution and reproduction in any medium or format, as long as you give appropriate credit to the original author(s) and the source, provide a link to the Creative Commons license, and indicate if changes were made. The images or other third party material in this article are included in the article's Creative Commons license, unless indicated otherwise in a credit line to the material. If material is not included in the article's Creative Commons license and your intended use is not permitted by statutory regulation or exceeds the permitted use, you will need to obtain permission directly from the copyright holder. To view a copy of this license, visit http://creativecommons. org/licenses/by/4.0/.
\end{abstract}

(c) The Author(s) 2020 